\title{
Framing Research: Conceptualization, Contextualization, Representation and Legitimization
}

\author{
Phillip G. Payne ${ }^{1}$
}

\begin{abstract}
Concerns have been expressed about the identity, value and usefulness of environmental education research in the anglo-speaking North/West. As environmental education research becomes globalized, important lessons might be learned in the South about trends in Northern environmental education and emerging issues in environmental education research. The Introduction outlines the risks in explaining how environmental education and its research is configured. The paper, first, summarizes the major 'currents' in environmental education curriculum and pedagogical practices and, second, highlights some of the major implications for environmental education research. The notion of 'framing' is introduced to provide a set of concepts for researchers to more creatively examine the assumptions they make in approaching their scholarly work while also encouraging a greater degree of reflexivity about the field's future. This future might incorporate an aesthetics into the ethics and politics of research and, in doing so, respond more sensitively to the need for greater attention to be devoted to developing the triad of ontology, epistemology, methodology in environmental education research and its praxis. An emphasis on the art and craft of framing invites researcher(s) to critically assess the conceptualization, contextualization, representation and legitimization of research 'work,' both the individual researcher's and the field' identity, value and usefulness. Examples of the author's research are used to illustrate the notion of framing. An earlier version of this paper was delivered at $V$ EPEA Encontro de Pesquisa em Educacao Ambiental "Configuracao do Campo de Pesquisa em Educacao Ambiental" (30 de octubro a 2 de novembro de 2009) and uses information from a preconference 3 day workshop conducted by the author at the Universidade Federal de Sao Carlos.
\end{abstract}

Keywords: environmental education research, framing, reflexivity, conceptualization, contextualization, representation, legitimization, aesthetics, ethics, politics, ontology, epistemology, methodology.

Resumo: Nos países anglófonos do Norte e do Ocidente, tem havido demonstrações de preocupação quanto à identidade, ao valor e à utilidade da pesquisa em educação ambiental. À medida que a educação ambiental se globaliza, torna-se possível para o Sul aprender lições referentes às tendências da educação ambiental praticada no Norte e às questões emergentes na pesquisa em educação ambiental. A Introdução deste artigo esboça os riscos envolvidos na explicação de como a

1 Professor da Monash University, Australia. Contato: Monash University, Faculty of Education. PO Box 527, Frankston, Victoria, 31199, Austrália. phillip.payne@monash.edu 
educação ambiental e a sua pesquisa estão configuradas. Em primeiro lugar, resumem-se as grandes correntes do currículo em educação ambiental e das práticas pedagógicas; em segundo lugar, destacam-se algumas das mais importantes implicações da pesquisa em educação ambiental. Introduz-se a noção de "enquadramento" a fim de dotar os pesquisadores de um conjunto de conceitos que lhes possibilite examinar de modo mais criativo as hipóteses que eles mesmos abordam no seu trabalho de pesquisa, ao mesmo tempo que se encoraja um maior grau de reflexividade sobre o futuro do campo. É possível que esse futuro incorpore uma estética à ética e à política de pesquisa e, ao fazer isso, forneça respostas mais sensíveis à necessidade de se dar mais atenção ao desenvolvimento da tríade ontologia-epistemologia-metodologia no contexto da pesquisa em educação ambiental e da sua práxis. Uma ênfase na arte e na técnica do enquadramento convida o(s) pesquisador(es) a avaliar criticamente, por um lado, a conceitualização, contextualização, representação e legitimação do "trabalho" de pesquisa, e, por outro lado, a identidade, o valor e a utilidade tanto do pesquisador em sua individualidade quanto do campo. Exemplos da pesquisa deste autor são usados para ilustrar a noção de enquadramento. Uma versão prévia deste artigo foi entregue no V EPEA (Encontro de Pesquisa em Educação Ambiental), "Configuração do Campo de Pesquisa em Educação Ambiental", realizado entre os dias 30 de outubro e 2 de novembro de 2009. Essa versão retoma algumas considerações oriundas de uma oficina de pré-conferência realizada pelo autor na Universidade Federal de São Carlos ao longo de três dias.

Palavras-chave: Pesquisa em Educação Ambiental, Enquadramento, Reflexividade, Conceitualização, Contextualização, Representação, Legitimação, Estética, Ética, Política, Ontologia, Epistemologia, Metodologia.

\section{INTRODUCTION}

Thank you for the kind invitation to describe the configuration of environmental education and examine trends in environmental education research. I will focus on one key trend in environmental education research - the need to pay greater attention to the 'framing' of research where its art and craft potentially makes a significant contribution to the originality and elegance, and value and usefulness, of the research endeavour.

There are, however, some pre-requisite understandings needed about the field's past and current configurations before the idea of framing can be developed. This task is difficult. The configurations of environmental education curricula and pedagogical practices and the field's research are, indeed, complex and 'messy' as John Law (2004) has concluded about social science research. For example, complexity is self-evident in the transitions from modernity to postmodernity (Payne, 1999, 2006), and from environmental education to a globalized education for sustainable development (for example, Jickling \& Wals, 2008). Each of those epochal, paradigmatic and educational 'shifts' in the discourse of environmental education has been debated in the anglo-speaking 
North/West. Similar concerns have been discussed in Pesquisa em Educacoa Ambiental (for example, Freire, 2007; Gallo, 2008).

The changing configurations of both the pedagogical/curricula and research/scholarly inquiry fields are, indeed, shaped by a wide range of demographic, geographical, historical, linguistic, social, technological, cultural, global and 'ecological' factors. The configuration of the research field is also specifically shaped by the way researchers understand the ontological, epistemological, axiological and methodological underpinnings, insights and assumptions they make in their works, individually and collectively, and then represent them at conferences and in publications as a record of the field's achievements and aspirations. That is, the knowledge researchers produce constitutes a basic socio-cultural construction of the discourse of environmental education. It is fallible. Put differently, there are competing views about research knowledge and its epistemologies of production (Gamboa, 2007; Robottom, 2006), interests and ideologies, and questions of access, value, use and usefulness. Moreover, underlying this messy complexity, researchers must remain vigilant to how the fields of environmental education practice and research are reconstituted knowingly and unknowingly by the 'frames' they and others employ. The latter is the major task of this article.

What major issues arise for research development from this diversity? First, in the anglo-speaking north/west from where I think, practice and write, there are now numerous versions of environmental education pedagogy, curricula and research. While this diversity is a healthy sign for the field and for democracy, there is growing concern about the overall strategic value and historical usefulness of the field, its lack of a coherent identity and sense of collective purpose, the declining quality of research and $\mathrm{PhD}$ training, the mismatch of means and ends in research and, subsequently, what future awaits environmental education (for example, Hart, 2003; Reid \& Scott, 2006; Reid, 2009, McKenzie et al., 2009; Scott, 2009).

To exemplify the rise of diversity, Lucie Sauvé's (2005) identification of 15 'currents' highlights the pedagogical and curricula trends making up the field's configuration. It is discussed in more detail below. Trends demand critical scrutiny. For example, one is the development of 'ecopedagogies' that aim to satisfy the different learning needs of students. Arguably, this might be an example of the aspiration to 'individualize' the learning/teaching process now typical in the relatively rich North/West. However, debate about the social and ecological implications of that resource intensive, constructivist trend has not yet occurred. Curriculum development must also contend with an increasing array of environmental problems. For example, climate change is a global problem with significant local consequences. Only recently has the global-local tension attracted much attention in curriculum development. Again and more broadly but lacking in critical debate, the need to find quick political and pedagogical solutions might obscure the fact that climate change is only one amongst many socio-cultural-ecological problems that need to be tackled (Diamond, 2005, Nielsen, 2005). For example, the wastage of food in the North/West is a massive 
resource and environmental problem that has attracted very little interest in environmental education.

There is a second reason why it is risky to comment confidently on the configuration of the field. The increasingly complex configuration of North/West versions of environmental education and its research may or may not be relevant to 'other-than-anglo' settings and cultures, such as what can be found in Brazil (Reigota, 2007). For example, do Brazilian youth and their families waste as much food as their Australian counterparts? The relevance, therefore, of an anglo-north/west $<-\rightarrow$ other-than-anglo 'critical dialogue' raises interesting research questions about globalization and its effects on education research (Kenway \& Fahey, 2008). We might therefore ask what is distinctive and important in Brazil about environmental education and its research (Marin, 2008; Reigota, 2007)? Is it similar or different to what we find in Australia? Or Canada? We can ask, therefore, about the significance of a 'habitus' or 'place' or locale of our research work in Brazil, or Australia, and to what extent the notion of a particular habitus of environmental education can still exist in, for example, Sao Carlos when its everyday lifeworld is constantly being transformed by the invisible and visible forces of globalization's technologies and economics (Payne, 2006b).

A third reason exists for problematizing any explanation of the configuration of environmental education. Rather than lag behind pedagogical practices, it might be timely for researchers to take a lead in deliberating about the future of the increasingly complex configuration of the field. Put simply, if environmental education research is to develop educational viability and identity, social credibility and political usefulness, then a major challenge for the field's scholars is to make some 'common sense' about the field's diversity and, ultimately, messiness and confusion. While it is right to cautiously celebrate that plurality, the field's diversity might obstruct any determination for a more common, valuable and useful 'end-in-view'. Again, there has been a lack of discussion and debate in the North/West about diversity and plurality being valued as a means or as an end. The latter seems to prevail and, hence, might be a cause of the concerns now being expressed by some scholars about the lack of identity, purpose, value and usefulness.

Against this backdrop of complexities, difficulties and messiness, the main purpose of this article is to ask the question of how we 'frame' environmental education research and, by implication, say something for and about environmental education in a period of its rapid diversification, pluralism, globalization and reflexivity. By framing, I mean how we conceptualize, contextualize, represent and legitimize the intellectual work and exchange of ideas we undertake locally, nationally and now globally and more abstractly. Framing demands that we ask simple but sophisticated questions about the field and its discourses' past, present and future achievements, interrogate the assumptions and interests we have in environmental education research, pose serious and important research questions, be conscientious in the conduct of research and be clear about whose and what interests are being served by the knowledge produced and disseminated 
via research. It asks us to be far more diligent and reflective about the theory(ies) of knowledge we hold to while being clearer about their means and processes of production. Framing demands a heightened reflexivity about our roles as 'knowledge producers' and the implicitly or overtly stated 'value theory' and 'meaning-making' aspects of our contribution to the commonsense of the field in which we work democratically for a wide range of participants and audiences - learners, educators, curriculum policy makers and other researchers (Payne, 2010a). It invites us to question whether or not, and to what extent, environmental education research, has produced a valuable body of knowledge and coherent literature base that is useful in various situations and contexts ranging from small to large scale.

Finally, by way of introduction, I am acutely aware of the problems associated with 'experts' from the anglo speaking West/North advising or recommending solutions to the practitioners and scholars in a 'home' nation such as Brazil. In introducing the notion of framing, it is doubtful that a colonizing logic is being reproduced. Framing is merely a form of posing fundamental questions for the field and matching them with considered research conceptualization, development, enactment, interpretation and dissemination. Due to my numerous stays and visits to various countries in South America over the past 25 yeas, I hope I am sensitive to the possibility of the field's identity colonization (Payne, 1997; Gonzalez-Gaudiano \& Buenfil-Burgos, 2009) and, how, potentially the increased globalization and mobility of experts and technological knowledge transfer can create serious challenges at the local and national level (Payne, 1999, 2006b). Equally, however, within the globalization of environmental education research, I am interested in how we might 'imagine' our work differently (Kenway \& Fahey, 2008), particularly when concerns about the field's North/West configuration, trends, identity, value and usefulness are being expressed. We are beginning to see this in environmental education theory in the North/West (McKenzie, Hart, Bai \& Jickling, 2009). And there are positive signs in Brazil (Reigota, 2007, Santos, 2007).

\section{Configuration of environmental education - the main currents of curricula/pedagogical practice}

Lucie Sauvé's (2005) 'currents' demonstrate the diversity and complexity of environmental education practices as they have evolved in the North/West. There is also a different 'political' reason for including Sauvé's currents. Given the evolution of practices, environmental educators and researchers now need to demonstrate greater 'reflexivity' about the field's identity, diversity, means and ends, value, achievements and usefulness.

Sauvé's (2005) currents demand we acknowledge, at the very least, the need for a critical and comprehensive view of research and how we make some sense of its' purposes and directions in relation to the expanding scope of environmental education practices. No longer can environmental education researchers simply reproduce a standard 'one size fits all' approach to research 
questions, issues, trends and problems. Nor is the 'old' quantitative versus qualitative 'debate' as useful as what it once was. Within the plurality of Sauvé's currents, there is a warrant for researchers (and the field) to respond carefully, sensitively and critically to a wide range of issues raised about the various problems and questions now being raised reflexively about the value and usefulness of environmental education research. More broadly, this elevated reflexivity in environmental education research is symptomatic of the 'reflexive modernization' phenomena described in social and cultural theory (for example, Beck, Giddens \& Lash, 1994; Archer, 2007).

In regard to the changing configuration of environmental education, many of its researchers share a rich and diverse history that commenced 'officially' in the West in the 1970s with a series of United Nations conferences (Palmer, 1998). Clearly, those foundations have evolved over time, space and cultural/national identities through the development of National Associations, Conferences, Journals and numerous other means. So, Sauvé's (2005) 'currents' highlights the contemporary diversity of the curriculum/pedagogical field in the North/West.

Sauvé (2005) does not trace each current's evolution, status, or legitimacy over time and place, or according to different nation state curriculum expectations or their theoretical and ideological framings. Sauvé's currents do illustrate how the field has evolved from the earlier characterizations of environmental education in the 1980s and 90s as being in, about or for the environment that then served the field well in delineating the 'ideology' of the field (for example, Fien, 1993) and debates about it in environmental education research (Robottom \& Hart, 1993).

Indeed, research innovation seems to pragmatically lag behind environmental education curriculum and pedagogical practices that, also pragmatically, focus on concerns about schooling, learning and learners, programs or interventions, or tools and techniques, and teaching (Reid \& Scott, 2006). Although suggestive in some currents, Table 1 does not include for environmental education researchers any 'detailed' identification of a research design or methodology 'best' suited to fitting the current, or matching the conception of environment (or nature), or assessing the usefulness of the aims, or judging the value of the dominant approaches.

To be sure, the environmental education research field's current configuration is now far more complex with new genres of inquiry emerging primarily from 2000 (Russell \& Hart, 2003). Some of the strategies listed as examples in Table 1 are suggestive of the type of research that might be 'commensurable' with the traditional and emerging aims and means, or approaches. For example, it is most likely that a positivist inspired, semi experimental type study might be seen as the best fit for the traditional if not hegemonic 'scientific' approach to curricula/pedagogy identified by Sauvé. An interpretive phenomenological/ethnographic approach might be most appropriate for an emergent form of eco-education and ecopedagogy. Participatory research committed to a social praxis calls for a particular view of 
epistemology and methodology and has been discussed earlier in this journal (Robottom, 2006). And so on. However, we do need to be cautious about the mix of pragmatism in pedagogy and research in environmental education (Raven, 2006). Dillon and Wals (2006) have cautioned about the dangers of blurring methods, methodologies and ideologies in environmental education research.

Table 1. Sauvé's (2005) currents (reproduced with personal permission from Lucie Sauvé)

\begin{tabular}{|c|c|c|c|c|}
\hline Current & $\begin{array}{l}\text { Conception of } \\
\text { Environment }\end{array}$ & $\begin{array}{c}\text { Aims of Environmental } \\
\text { Education }\end{array}$ & $\begin{array}{c}\text { Dominant } \\
\text { Approaches }\end{array}$ & Examples of Strategies \\
\hline Naturalist & Nature & $\begin{array}{l}\text { Reconstruct a link with } \\
\text { nature. }\end{array}$ & $\begin{array}{l}\text { Sensorial, Cognitive, } \\
\text { Affective, Experiential, } \\
\text { Creative/Aesthetic }\end{array}$ & $\begin{array}{l}\text { Immersion; Interpretation; } \\
\text { Sensorial games; Discovery } \\
\text { activities. }\end{array}$ \\
\hline $\begin{array}{l}\text { Conservationist/ } \\
\text { Resourcist }\end{array}$ & Resource & $\begin{array}{l}\text { Adopt behaviours compatible } \\
\text { with conservation. } \\
\text { Develop skills related to } \\
\text { environmental management. }\end{array}$ & Cognitive, pragmatic & $\begin{array}{l}\text { Guide or code of } \\
\text { behaviour; } 3 \text { Rs set of } \\
\text { activities; Environmental } \\
\text { audit; Conservations } \\
\text { project. }\end{array}$ \\
\hline Problem-solving & Problem & $\begin{array}{l}\text { Develop problem-solving } \\
\text { skills: from diagnosis to } \\
\text { action. }\end{array}$ & Cognitive, pragmatic & $\begin{array}{l}\text { Case study: issue analysis; } \\
\text { Problem-solving project. }\end{array}$ \\
\hline Systemic & System & $\begin{array}{l}\text { Develop systemic thinking: } \\
\text { analysis and synthesis, } \\
\text { towards a global vision. } \\
\text { Understand environmental } \\
\text { realities in view of } \\
\text { enlightened decision-making. }\end{array}$ & Cognitive & $\begin{array}{l}\text { Case study: environmental } \\
\text { system analysis; } \\
\text { Construction of ecosystem } \\
\text { models. }\end{array}$ \\
\hline Scientific & Object of study & $\begin{array}{l}\text { Acquirre knowledge in } \\
\text { environmental sciences. } \\
\text { Develop skills related to the } \\
\text { scientific method. }\end{array}$ & Cognitive, Experiential & $\begin{array}{l}\text { Study of phenomena; } \\
\text { Observation; Demonstra- } \\
\text { tion; Experimentation: } \\
\text { Hypothetico-deductive } \\
\text { research activity. }\end{array}$ \\
\hline $\begin{array}{l}\text { Humanistic/ } \\
\text { Mesological }\end{array}$ & Living Milieu & $\begin{array}{l}\text { Know and apreciate one's } \\
\text { milieu of life: better know } \\
\text { oneself in relation to this } \\
\text { living milieu. } \\
\text { Develop a sense of belonging. }\end{array}$ & $\begin{array}{l}\text { Sensorial, Affective, } \\
\text { Cognitive, Experiential, } \\
\text { Creative/Aesthetic }\end{array}$ & $\begin{array}{l}\text { Itinerary; Landscape } \\
\text { reading; Study of milieu; } \\
\text { Investigation. }\end{array}$ \\
\hline Value-centred & Field of values & $\begin{array}{l}\text { Adopt ecocivic behaviours. } \\
\text { Develop a system of ethics. }\end{array}$ & $\begin{array}{l}\text { Cognitive, Affective, } \\
\text { Moral }\end{array}$ & $\begin{array}{l}\text { Analysis of values; } \\
\text { Clarification of values; } \\
\text { Criticism of social values. }\end{array}$ \\
\hline Holistic & $\begin{array}{l}\text { Holos, Gaïa, All, } \\
\text { The Being }\end{array}$ & $\begin{array}{l}\text { Develop the many } \\
\text { dimensions of one's being in } \\
\text { interaction with all aspects of } \\
\text { the environment. } \\
\text { Develop an "organic" } \\
\text { understanding of the world } \\
\text { and participatory action in } \\
\text { and with the environment. }\end{array}$ & $\begin{array}{l}\text { Holistic, Organic, } \\
\text { Intuitive, Creative }\end{array}$ & $\begin{array}{l}\text { Free exploration; } \\
\text { Visualization; Creative } \\
\text { workshops; Integration of } \\
\text { complementary strategies. }\end{array}$ \\
\hline Bioregionalist & $\begin{array}{l}\text { Place of } \\
\text { belonging, } \\
\text { Community } \\
\text { project }\end{array}$ & $\begin{array}{l}\text { Develop competencies in/for } \\
\text { local or regional community } \\
\text { ecodevelopment. }\end{array}$ & $\begin{array}{l}\text { Cognitive, Affective, } \\
\text { Experiential, Pragmatic, } \\
\text { Creative }\end{array}$ & $\begin{array}{l}\text { Exploration of our shared } \\
\text { milieu; Community } \\
\text { project; Project of local or } \\
\text { regional ecodevelopment. }\end{array}$ \\
\hline Praxic & $\begin{array}{l}\text { Locus of } \\
\text { action/reflection }\end{array}$ & $\begin{array}{l}\text { Learn in, by, and for } \\
\text { environmental action. } \\
\text { Develop reflexive skills. }\end{array}$ & Praxic & $\begin{array}{l}\text { Action-research; Reflexive } \\
\text { postura in activities or } \\
\text { project. }\end{array}$ \\
\hline Socially Critical & $\begin{array}{l}\text { Object of } \\
\text { transformation, } \\
\text { Place of } \\
\text { emancipation }\end{array}$ & $\begin{array}{l}\text { Deconstruct socio- } \\
\text { environmental realities in } \\
\text { view of transforming them } \\
\text { and transforming people in } \\
\text { this process. }\end{array}$ & $\begin{array}{l}\text { Praxic, Reflexive, } \\
\text { Dialogic }\end{array}$ & $\begin{array}{l}\text { Analysis of discourses; } \\
\text { Case study; Debate; } \\
\text { Action-research. }\end{array}$ \\
\hline Feminist & $\begin{array}{l}\text { Object of } \\
\text { solicitude }\end{array}$ & $\begin{array}{l}\text { Integrate feminist values into } \\
\text { the human-environment } \\
\text { relationship. }\end{array}$ & $\begin{array}{l}\text { Intuitive, Affective, } \\
\text { Symbolic, Spiritual, } \\
\text { Creative/Aesthetic }\end{array}$ & $\begin{array}{l}\text { Case study, Immersion, } \\
\text { Creative workshop, } \\
\text { Communication \& } \\
\text { exchange activity. }\end{array}$ \\
\hline
\end{tabular}




\begin{tabular}{|c|c|c|c|c|}
\hline Ethnographic & $\begin{array}{l}\text { Territory, Place of } \\
\text { identity, } \\
\text { Nature/culture }\end{array}$ & $\begin{array}{l}\text { Recognize the close link } \\
\text { between nature and culture. } \\
\text { Clarify one's own cosmology. } \\
\text { Valorize the cultural } \\
\text { dimensiona of one's } \\
\text { relationship with the } \\
\text { environmental. }\end{array}$ & $\begin{array}{l}\text { Experiential, Intuitive, } \\
\text { Affective, Symbolic, } \\
\text { Spiritual, } \\
\text { Creative/Aesthetic }\end{array}$ & $\begin{array}{l}\text { Fables, Stories and } \\
\text { legends; Case study; } \\
\text { Immersion; Modelling; } \\
\text { Mentoring. }\end{array}$ \\
\hline Eco-Education & $\begin{array}{l}\text { Role of interaction } \\
\text { for personal } \\
\text { development. } \\
\text { Local of identity } \\
\text { construction }\end{array}$ & $\begin{array}{l}\text { Experience the environment } \\
\text { to experience oneself and to } \\
\text { develop in and through it. } \\
\text { Construct one's relationship } \\
\text { with the "other-than-human } \\
\text { world". }\end{array}$ & $\begin{array}{l}\text { Experiantial, Sensorial, } \\
\text { Intuitive, Affective, } \\
\text { Symbolic, Creative }\end{array}$ & $\begin{array}{l}\text { Life story; Immersion; } \\
\text { Exploration; Games; } \\
\text { Introspection; Sensitive } \\
\text { listening; } \\
\text { Subjective/objective } \\
\text { alternance. }\end{array}$ \\
\hline $\begin{array}{l}\text { Sustainable } \\
\text { Development/ } \\
\text { Sustainability }\end{array}$ & $\begin{array}{l}\text { Resource form } \\
\text { economic } \\
\text { development. } \\
\text { Shared resource } \\
\text { form sustainable } \\
\text { living }\end{array}$ & $\begin{array}{l}\text { Promote economic } \\
\text { development that takes care } \\
\text { of social equity and ecological } \\
\text { sustanability; Contribute to } \\
\text { such development. }\end{array}$ & Pragmatic, Cognitive & $\begin{array}{l}\text { Case study; Social } \\
\text { marketing; Sustainable } \\
\text { consumption activities; } \\
\text { Sustainable living } \\
\text { management project. }\end{array}$ \\
\hline
\end{tabular}

Pragmatically-driven research interest about epistemological issues in education, however, tends to dominate in the North/West. There is consequential concern about methodological issues and development. Education and curriculum policies are rarely influenced. The initial framing of research endeavours are barely explained or justified in terms of the broader value and perceived usefulness of the research purposes and problem resolution. Research too often takes the form of evaluations of curriculum programs or pedagogical interventions, or is presented as descriptive reports that are rightly vulnerable to allegations of it being atheoretical and 'snapshot' only in form. While such 'research' might serve an immediate pragmatic purpose, this approach to its framing, design and development might inevitably act as a limit on the field's scholarly development and overall growth. Indeed, Reid and Scott (2006, p. 572) link the increasing diversity of the field to research that they believe is like 'low hanging fruit' because it is "safe, convenient and conventional." But such diversity, as illustrated by Sauvé's currents, does present challenges about their contextual appropriateness and pedagogical adequacy to the environmental educator working at the 'grassroots' level.

More generally, despite the proliferation of North/West writings about environmental education over the past 15 - 20 years ranging from notions like 'ecological literacy' (Orr, 1992) to children's 'nature-deficit disorder' (Louv, 2005) to 'place-pedagogy' (Greenwood \& Smith, 2008), all of which lack clearly articulated implications for the framing of research, a number of observations can be made about the changing dynamic and configuration of environmental education.

- The field of environmental education has evolved dramatically since the 1970s. Dominant early was the applied science perspective or positivist like approach whose priority was the delivery by knowledgeable treachers of factual knowledge 'about' and often 'in' the environment. In the 1990s, a more 'political' socially critical education 'for' the environment provided an alternative. It was often theoretically based on the works of Jurgen Habermas and Paolo Freire. Participatory and action-oriented pedagogies embraced 'social justice' imperatives around local environmental issues and 
problems. From the mid 90s there has been an explosion of views and approaches to environmental education, as summarized in Table 1. Some have been driven by the rise of information technologies and the abstracted mode of intellectual exchange required by that form of globalized discourse, others by the shift to the global logic of education for sustainable development. Others are more textual and mirror the linguistic and discursive 'turns' in social theory. Some other currents reflect the 'corporeal turn' in social theory and emphasize a more organic, affective 'experiential' and 'interdisciplinary' locus, focus and purpose of environmental education.

- There is increasing diversity in the field that should be a) celebrated for its inclusion of different viewpoints and b) criticized, if that diversity is not valuable in terms of having an effect on change and/or coalescing the field around a relatively common purpose and end-in-view.

- The field in the North/West might has evolved to a 'relational' view of environmental education that reflects a 'socio-ecological' theory of how education can deal more assertively with the 'intersections' of the culturenature and human-environment relations and their requisite pedagogies, curricula and ethics and politics. If so, Sauvé's (2009) trend analysis in Table 2 of three complementary perspectives in contemporary environmental education is, again, helpful in pointing towards a potential commonality of the field amongst the messy trend to diversity and complexity. Again, it is unclear what the implications of a broader, still emergent socio-ecological theorization of environmental education are for environmental education research and scholarly development.

\section{Table 2. A relational, socio-ecological approach to environmental education - an emerging theoretical 'frame'}

Three Complementary Perspectives in Environmental Education

\begin{tabular}{|c|c|c|c|}
\hline Perspective & Main Issue & $\begin{array}{c}\text { Nature of } \\
\text { Environmental Education }\end{array}$ & Focus \\
\hline Socioecological & $\begin{array}{l}\text { Degradation of life systems and } \\
\text { depletion of resources. } \\
\text { Siparity of access to resources. }\end{array}$ & $\begin{array}{l}\text { A strategy to promote } \\
\text { environmental problem solving and } \\
\text { management and eco-development. }\end{array}$ & $\begin{array}{l}\text { The quality of the environmental as a } \\
\text { living milieu. } \\
\text { The quality of life for human } \\
\text { populations. } \\
\text { Empowerment in/ for critical action. }\end{array}$ \\
\hline Educational & $\begin{array}{l}\text { A deep rupture between } \\
\text { humans and nature, related to } \\
\text { the many forms of rupture } \\
\text { between humans and within } \\
\text { and between societies. }\end{array}$ & $\begin{array}{l}\text { An integrating and fundamental } \\
\text { dimension of a holistic educational } \\
\text { project. } \\
\text { A life-long journey of personal and } \\
\text { social development in relation to } \\
\text { the environment. }\end{array}$ & $\begin{array}{l}\text { The quality of being, at the } \\
\text { individual and social levels. } \\
\text { The achievement of an ecological } \\
\text { self: belonging, resilience, care, and } \\
\text { involvement. }\end{array}$ \\
\hline Pedagogical & $\begin{array}{l}\text { The inadequacy of the usual } \\
\text { teaching-learning processes to } \\
\text { construct environmental, } \\
\text { trasnformative learning. }\end{array}$ & $\begin{array}{l}\text { A contribution to a more relevant } \\
\text { educational process to enhance our } \\
\text { relation to the environment. }\end{array}$ & $\begin{array}{l}\text { The quality of education through } \\
\text { the ecologization of schools and } \\
\text { curricula. } \\
\text { The development of an eco- } \\
\text { pedagogy. }\end{array}$ \\
\hline
\end{tabular}


Sauvé's (2009) use of terms like 'integrating,' holistic,' life-long,' 'quality of life,' 'being,' 'ecological self,' 'belonging,' and 'ecologization' is interesting and highly suggestive for what such a conceptual trend implies about the way we think about environmental education and, reflexively and critically, for environmental education research. The possibility, therefore, of an 'ecocentric' approach to the framing of research is discussed below.

Finally, in this dynamic evolution of the configuration of environmental education practices, as suggested by, for example, Sauvé (2005, 2009), a new language with different terms is being used in theorizing environmental education. In a socio-ecological and ecocentric trend there potentially are many 'layers in layers' of environmental education making up the field's complexity. No doubt, different metaphors, currents and ideologies remain in conflict hence a stable configuration of the field remains a struggle.

\section{Configurations, trends/issues in environmental education research.}

Before I develop the crucial question of research framing, it is important to, again, highlight the configurational complexity of trends and issues in environmental education research. To simplify this task, I draw on an analysis by Alan Reid and Bill Scott (Editors of Environmental Education Research - EER) of articles published in the first 10 years of that journal (Reid \& Scott, 2006). Other sources can be drawn upon to outline the configuration of research. Moreover, discussion about the relation of environmental education and emerging genres of environmental education research has been going on in earnest for the last decade (Robottom \& Hart, 1993; Hart \& Nolan, 1999; Russell \& Hart, 2003; Hart, 2005; Reid, 2009). But this debate has achieved little so far in terms of settling, establishing or imagining the field's identity, sense of value and relatively common usefulness.

In terms of the configuration of the field of environmental education research, Reid \& Scott's (2006) analysis of articles published in Volumes, 1, 4, 7 and 10 of the first 10 years of EER is very helpful in identifying trends in research and changing emphases. They discuss these trends and issues in considerable detail and should be read. Here, I add a few observations.

\section{(i) The primary field of articles in Environmental Education Research}

EER clearly differentiates between research that focuses on a notion of environmental education and research that pertains to a notion of sustainable development education. The vast majority of articles published are about environmental education.

\section{(ii) The specialist areas in articles in Environmental Education Research}

EER differentiates between research that is conceptual, programmatic or policy, the provision of EE/SDE, theory and research-related. While 
conceptually focused understandings are constantly published, there is growing interest in research methods, designs and approaches, the latter of which endorse the importance attached here to elaborating a notion of framing.

\section{(iii)The sample, scope or settings in articles in Environmental Education Research}

Much research focused on formal primary and secondary provision of environmental education, or schooling, and therefore a constrained notion of education that, for example, can exclude or not represent other settings such as the family home, the neighbourhood. While the research published does focus on schooling, Reid \& Scott (2006) do not delineate what 'currents' of environmental education might have been studied in formal settings.

\section{(iv) The 'researched' in articles in Environmental Education Research}

Research on learners, educators and policy/curriculum dominates and is consistent over time suggesting, again, formal schooling attracts a great deal of interest. Again, Reid and Scott do not identify what the currents of environmental education were in which the 'researched' were involved.

\section{(v) Nature of data used in articles in Environmental Education Research}

There is a 'balance' of empirical and non-empirical studies, hinting that speculation, commentary and criticism (non empirical) have been valued by EER and, possibly, relate to the conceptual development of the field (see ii above). Within empirical studies, there have been many more qualitative studies than quantitative studies, confirming a conclusion made by Hart \& Nolan (1999) about trends in environmental education research

\section{(vi) Principal analysis used in articles in Environmental Education Research}

While there is a 'balance' of empirical and non-empirical studies and within empirical studies of three types (qualitative, quantitative and mixed) we are unable to ascertain what type of conceptual or theoretical analysis occurred in the non-empirical studies such as, for example, a poststructural critique, a historical interpretation, a phenomenological perspective, a feminist reading.

\section{(vii) Gender of the principal author of articles in Environmental Education Research}

Although females are increasingly represented, males dominate. There is no data, by gender, about whose manuscript is rejected, nor about the affiliation by gender to a 'current.' 


\section{(viii) Continental location of the principal author of articles in Environmental Education Research}

EER is published in English and attracts authors/researchers primarily from the anglo-speaking north/west. South Americans are under represented while Europeans and North Americans are well represented, noting there are national journals from Australia, Canada, Southern Africa and USA. The Brazilian journal was first published in 2006. Each of the journals listed above has a limited number of issues per volume. Some publish a large number of articles while others publish a few. EER remains the dominant journal and now publishes 6 editions in an annual volume. There is no data, by continental location, about whose manuscript is rejected, nor about the affiliation by continental location to a 'current.'

In further illustrating the complexity, trends and fluid configuration of the field, listed below are the titles of Special Issues that have appeared in Environmental Education Research from 2000-2009. For the purposes here *signifies Special Issues that have primarily focused on research 'development' while others focus on substantive issues relevant to the 'conceptualization' and /or 'contextualization' of research.

1. * Qualitative methods of inquiry

2. The language of sustainability

3. * Learners and learning in environmental education: A critical review of the evidence

4. On the possibility of education for sustainable development

5. * Reviewing research in environmental education: extended critical reflections

6. $*$ Exploring the gap

7. * Case study research

8. Environmental education research and social change: Southern African perspectives

9. Natural capital; Metaphor, learning and human behaviour

10. * Transitions in thought and practice: Links, divergences and contradictions in postcritical inquiry

11. Free choice learning and the environment

12. Environmental education in three German-speaking countries

13. * Researching education and the environment

EE and ESD; tension or transition

Locating the environmental in EER

Doing environmental education research

Environmental learning as process and outcome

Environmental education for...

Developing environmental education research

14. Revisiting schooling and environmental education: Contradictions

15. Childhood and environment 
16. Education for sustainable development in higher education

17. Sustainability in higher education research

18. Children's literature and place

19. Environmental education research in Sweden and Denmark

Seven Special Issues focus sharply on research development or issues. The remaining 12 focus on a wide range of topics, noting that EER welcomes recommendations from authors about themes for Special Issues. Of course, other environmental education journals and conferences have had special themes or foci.

Reid \& Scott's (2006) analysis and interpretation of trends and issues in EER's published articles and the listing of Special Issues of EER illustrate the changing nature and increasing complexity of the evolving field of environmental education research between 1995-2004 and onto 2009. Similarly, Sauvé's (2005) currents reflect the growing diversity of environmental education.

\section{Value in the politic of environmental education research}

As a part of this dynamic and heightened reflexivity amongst environmental education researchers, Paul Hart (2003) raised a number of questions about researching for 'value' in environmental education. Hart's observations were made on the basis of his long-standing role for numerous journals as a critical reviewer of environmental education research. Hart's contribution is an important one, and published in one of the Special Issues listed above, named 'Reviewing Research in Environmental Education: extended critical reflections.' Hart's questioning of value in environmental education research is a retrospective reflection of a major review of research in environmental education between 1990 and 1999 he and Kathy Nolan undertook for Studies in Science Education (Hart \& Nolan, 1999). In his extended reflections, Hart incorporates a critical interpretation of another major 'meta review' of environmental education research undertaken by Mark Rickinson (2001) about what the research 'evidence' could say about 'learners and learning.'

Hart (2003, p. 244) acknowledged that his and Nolan's review was more concerned with separating democratic, progressive and critical aspects of research from those they felt were acquiescent, destructive or nihilistic. Hart also acknowledged concerns they felt about the reducibility of methodological issues to textual ones. He wanted to avoid bringing to 'closure' the way they interpreted the assumptions and meanings of the research they had reviewed. Hart reflected that reviewing environmental education research offered real challenges to the perceptual habits he carried into the way he understood research incorporated a range of assumptions about its conduct and reporting or dissemination. His reflexivity respinds to the question about the researcher also being researched and the reviewer being reviewed. Hart concluded that that such politics of review carried with it a heavy burden about questioning the value(s) of research. 
Hart's (2003) questioning of value was an important step towards similar concerns he has consistently expressed about the framing of environmental education research where the notion of framing might be seen more as a 'value theorization' composite of the interrelated concerns about how the research 'task' itself is conceptualized, contextualized, represented and legitimated. Hart's account of value in environmental education research comprises four intersecting claims made 'after' truths, awareness, ethos and politics. By 'truths,' Hart questioned to what extent research reviewed (be it a meta analysis, or a journal, or even a single study) can portray an understanding of what it is attempting to construct as a version of 'truth' or something approximating it. Hart noted that any construction - large scale or small - can only ever be partial, perspectival and situated and that a key of claiming 'truth' is to concede that claim is an 'interpretive construction' and an opportunity to generate a more adequate truth. 'Awareness,' therefore, for Hart, acknowledges on one hand that the synthesis of research can help 'settle' particular matters, concerns and interests in regard to a desire for knowledge accumulation and/or making judgements about methodological issues. But his account of awareness also points to the need for a disrupting of such 'settled' knowledge whose power has the potential to foreclose on the revealing of alternative ways of knowing (or seeing) so as to invoke contextual considerations that provide broader understandings of the phenomena under study. The value of 'ethos' lies in what Hart outlined is a need for improvisational quality within the interpretive stance undertaken by the reviewer of research. Or, the planner of a new research project, be it a $\mathrm{PhD}$ study or a major grant application. For Hart, an interpretive stance involves rumination about ideas, theories, methods and how each 'feeds off each other in 'opening' the possibility of research, rather than closing it, given the concession of the complexity of most phenomena we choose to study. Multiple perspectives, different theories, reworking researchable problems and questions and developing a 'constellation of images' about research and its work become part of Hart's call for a different 'ethos.'

Finally, for Hart the politics of knowledge production cannot be evaded. 'Politics' within the research endeavour is also another reflexive attempt to understand the power of the relationship between ontological and epistemological concerns as they pervade the subjects and setting of the research and how they interface with methodological deliberation and development. Hart attached great importance to exposing the 'historical-political-practical mindfulness' of environmental education research so that the 'embeddedness' of epistemological and methodological assumptions can be shifted in ways that a more responsive to the ethico-political demands of a re-engaged debate within the field. Hart's account of value concludes with an invitation to the reader to challenge the meanings of his inquiry into the place of value in reviewing research.

More recently, as Editor's of Environmental Education Research, Alan Reid and Bill Scott (2006) and Reid (2009) occupy a 'bird's eye view' and vantage point that push Hart's (2003) concerns about the 'value' of research towards 
concerns about its contemporary 'usefulness.' To mark the first 10 years of Environmental Education Research, a special Double Issue 'Researching education and the environment: retrospect and prospect' was compiled using a number of exemplary papers published in that first decade plus a number of invited, refereed commentaries about each exemplary paper. This Special Issue was organized around six themes that provide a thematic representation of some of the major themes, trends and issues in environmental education research. They include:

1. Environmental education and ESD: tension or transition?

2. Locating the environment in environmental education research.

3. Doing environmental education research.

4. Environmental learning as process and outcome.

5. Environmental education for...

6. Developing environmental education research.

Reid \& Scott (2006, p. xvi) identified three organizing ideas emerging from the above that 'frame' an expression of need in environmental education research, namely;

- Environmental education research as connected across interests, preferences, approaches, time and distance.

- Environmental education research foci needing attention.

- Sustainable development as inherently a learning process that needs researching by/with those involved in the dynamics of such learning.

There are, however, serious challenges confronting the field (Reid \& Scott, 2006) where, simply speaking, the 'means' of research do not fit well with, or match, the expanding 'ends' of environmental education (Reid, 2009). Put differently, inconsistencies and internal contradictions can often be found between (i) the aims/purposes and research questions (ii) the design, methodology and analytical/interpretive derivation of knowledge/findings (iii) the ways in which such knowledge production and its dissemination is (re)presented to its likely users (iv) the value of the research (v) the usefulness of the research in informing and enhancing decision-making of a) stakeholders b) building a credible body of knowledge called environmental education research that has political clout and ethical/intergenerational accountability and responsibility.

These and other concerns about the value and usefulness of environmental education research are exacerbated by the globalizing imperative and, therefore, the need for a politically critical consideration of the structures and transformations of knowledge production. 


\section{Globalizing structures and transformations of knowledge production}

In the North/West, there is growing concern that the role and identity of universities is undergoing rapid change as neo-liberal imperatives convert universities to a 'crisis' like condition where globalized approaches to knowledge production are viewed critically as a severe political threat (Coady, 2000; Cooper, Hinkson \& Sharp, 2002). James and McQueen-Thomson's (2002) summation of the sources of this crisis is very useful. It places the concerns expressed above about the value and usefulness of environmental education research into a broader political and historical context. They argue that the current dominant formation of knowledge is becoming more abstract as globalizing economic imperatives filter into academic settings, publishing houses, and the accountability of individualized academics and transition of universities into a nationally accountable, economic cultural logic that rarely, anymore, acts as a form of social conscience and progressive advancement of socio-ecological, humanitarian concerns. James and McQueen-Thomson argue that the process of abstraction represents a 'super-charged' process of a changing culture of inquiry that puts a hyper-intensified and individualized emphasis on rational codified investigation with increasingly commodifiable outcomes demanding greater accountability from academics and universities. Cooper (2002) used the term 'post-intellectuality' to describe the corrosive effects of the postmodern university and knowledge industry while Coady (2000) has lamented the decline of the university as a site for the ideals of inquiry, and its framing. Coady calls for a reinvigorated conversation about values, means and directions in much the same way Reid \& Scott (2006), and others such as Hart (2003), have called in environmental education research for more earnest framings of reflexive and critical inquiry that aspire to a greater coherence of purposes, means, values and end-in-view of useful research within the broader globalizing culture.

James \& McQueen (2002) identify five interrelated trends in knowledge production. First, knowledge production has become more rationalized. This trend has been enacted in abstract accounting mechanisms used for assessing research performance in ways that mirror Lyotard's (1984) thesis of the 'performativity' of knowledge and, therefore, academics, researchers, universities, journal and book publishing and even what exists in university libraries. A second major trend is towards the commodification of knowledge production where knowledge is increasingly linked with its globalized development as an 'export commodity' and 'industry.' Thus, the real potential of a colonizing logic and practice becomes self-evidently real for regions and countries 'other' than the North/West, as has been indicated in the Introduction. A third major trend in knowledge production is its codification. Knowledge here is viewed only as useful information that can be abstracted as data where, according to James \& McQueen, it is broken down into comparable, transferable, applied information bits. In this abstract form, information is then resolved into its discrete, constituent parts and then put back together in systematic form. A number of Nation States like the UK, Australia and New Zealand have legislated heightened 
auditing and accountability measures of performance where 'metrics' are used to assess the efficiency and productivity of this rationalization of knowledge, often according to government 'directions', of groups of academics and 'rankings' of universities. A fourth major trend in knowledge production and its abstracted notion of 'value' is that it has become increasingly mediated by a wider array of more intense technological apparatuses. The 'network' society (Castells, 1996) illustrates this proposition. It is readily apparent in how knowledge is 'transferred' and downloaded/uptaken increasingly in non face-to-face situations thus radically reconstituting the meaning and practice of terms like 'social' and 'pedagogy,' and ecocentric/ecological as they are contrasted with technocentrism (Payne, 2006b). The fifth trend is towards extension as a dimension of the processes of globalization. That is knowledge reified as global penetrates everywhere into the local, irrespective of context and circumstance. Relations are virtual and cyber-like.

According to James \& McQueen (2002, p. 189), when these five major trends of rationalization, commodification, codification, mediation and extension are taken together, they intensify each other and add up to a more abstract dominant mode of inquiry with globalizing consequences; the hegemony of analytical inquiry within a neo-liberal economic framework and imperative that, if so, marginalizes critical inquiry that is well framed in purposes, means and ends 'other' than that dominant logic, as is being observed in environmental education research and questions about its value, politics and usefulness. James \& McQueen see numerous consequences of the abstraction of knowledge production - changes in general publishing, changes in scholarly publishing, changes in journal publishing but also note a rise in dissent that must confront the 'excitement' of new technologies, the shift to electronic publishing, the role of libraries and other new directions. Cooper's (2002) critique of 'postintellectualism' argues that many academics now misrecognize the conditions of their own formation as 'intellectuals' and how their transformation is increasingly fused with the abstracted commodity form and corporatized mission of the postmodern university.

Rarely, is this larger critical context of knowledge production and dissemination acknowledged by those most affected by it.

\section{Framing as a response to challenges confronting the value and politics of environmental education research?}

Environmental education research must exhibit value, or an awareness and ethos of it (Hart, 2003) and be theoretically and/or empirically 'useful.' A challenge or threat is presented by the globalized politic and transformation of knowledge structures and their abstracted means of production (James \& McQueen, 2002). 'Low hanging' research (Reid \& Scott, 2006) is 'safe,' 'convenient' and 'conventional' - it tends to be simple and 'small-scale,' relatively insignificant because the research questions asked are 'modest,' designs/methodologies are 'old' and 'tired' and, therefore, the research is unlikely 
to be 'useful' and yield knowledge in, about and for the field, via the growth of the literature base in journals, conferences and $\mathrm{PhD}$ training.

Despite the proliferation of curriculum/pedagogical currents and emergence of new research genres, relatively conservative tendencies in environmental education research persist and, as Cooper (2002) argues is located in a 'post-intellectual' form where we find it difficult to see how we individually and collectively have been incorporated into an abstracted, corporate driven form of knowledge production. The sample, scope and setting of research published in EER understandably focuses on formal schooling (see iii above). Approach and design tend to reconstitute a 'one model fits all' view of research, although there is evidence of change, as described in some detail above. Much research is, in fact, not conceptually and/or theoretically driven but is 'evaluation' where, basically, an intervention is devised and its variables are identified and measured for significance of change. The dominant approach to evaluation mirrors a conservative positivist view of knowledge production and value, and a reductionist view of the sample and the phenomena under study. Evaluation studies typically use a semi-experimental design and case or comparative study approach where, typically, a classroom intervention is developed and implemented, then 'measured' via pre and post testing for 'shortterm' knowledge and/or attitudinal change that might occur but only in a specific context. While the evaluation study itself might be valid and reliable and useful to 'learning' in that specific pedagogical circumstance and curriculum/school context, the cause and effect logic of the findings cannot be generalized nor can the intervention be readily transferred to a different situation and context, without great difficulty. It is modest. This 'applied science,' evaluation (pre/post) semi-experimental type of logic has been most conspicuous in the Journal of Environmental Education from USA.

Much has already been written about these issues. In regard to the future configuration of environmental education research, there are numerous indicators about the emergence of a more vital and, possibly, dynamic and critical view of research development and inquiry in environmental education. What essentially is at stake for the diligent researcher, and the overall growth and credibility of the field of environmental education research, is how we understand the theory of knowledge and our role in knowledge production and its dissemination. Hence, the required reflexivity about framing given the complexity and messiness of the environmental education and environmental education research.

Hopefully a case has been made here that we must confront and critically examine our research frames, designs and methodologies. If framing is an important new trend in environmental education research in the North/West, we do need to carefully reconsider our assumptions and worldviews about the intention and value of our research. As a collective of researchers we should have a major interest in the agency of the field -- and facilitating the agency of those who work within it -- and the agency of those who are served by environmental education curriculum and pedagogy (learners and teachers)! We 
need to be very clear about the purposes, rationale, processes, contribution and value and usefulness of our individual and collective research efforts.

\section{Framing}

One important way of elaborating the idea of framing is to describe its major dimensions, noting each dimension interacts with the other dimensions in a mutually constitutive manner. Emphasizing the mutually constitutive nature of the different dimensions is a way of ensuring a greater degree of coherence, consistency and commensurability of the approach, purposes, means, ends-inview of research and its strategic usefulness to various audiences. Put simply, we are interested in the internal 'flow' of these dimensions as they pertain more broadly to reflexively understanding the assumptions, interests, values and political/globalizing structures of environmental education research - at individual and collective levels. Conceptually, the way in this notion of framing is outlined and described below makes clearer how an aesthetics of research requires a stronger presence in the ethics and politics of research as part of the adding of value to a broader conception of its usefulness. At the deepest theoretical and philosophical level, this notion of framing responds far more assertively to the requirement in research of a meaningful triad of ontology and epistemology as they underpin and inform methodological development.

The 'layered' dimensions incorporated into the framing of research include its;

- CONCEPTUALIZATION

- CONTEXTUALIZATION

- REPRESENTATION

- LEGITIMIZATION

Each is briefly characterized in a descriptive, practical manner. The conceptualization and contextualization of an approach to research, its formulation as problems and questions, selection of intellectual resources, and eventually its conduct and representation, are mutually constitutive. Framing is a highly creative act and, to a large degree, a major determinant of the originality of research. When the creative act of framing is enacted, or executed and conducted, as a form of praxis and well represented we may well speak about the elegance, value, usefulness and significance of research. If so, additional legitimacy is earned and warranted. In so doing, an aesthetic value is incorporated into the more customary acknowledgement of an ethics and politics in and of research. 


\section{(A) $\quad$ Conceptualization}

The conceptualization and contextualization dimensions of research reconstitute each other. The originality of research can be found in the art and craft of creatively developing a 'conversation' of the proposed concepts and likely contexts in which the research approach and activity is to be 'lived' by the researcher and the researched (Payne, 2005c). This imaginative conversation is challenging and time rich. A great deal of slow time should be devoted to conceptualizing the research. The modest 'low hanging fruit' of safe, convenient and comfortable research that Reid and Scott (2006) cautioned against, and heightening of value that Hart (2003) promoted and its politics of postintellectualism, remain salutary reminders.

What conceptual apparatus is available to creatively understand and interrogate likely research problems? What array of theories and intellectual resources critically inform the way we even think about a research problem or issue, or what our research is doing, or hopes to achieve - before we even get started?

Do I draw only on scientific understandings of climate change? Or do I draw inspiration from nature writers and poets? Or do I use learning theory developed by psychologists, or maybe anthropologists of experience? Is it timely in educational research to focus on meaning and embodied meaning as a necessary precursor to the dominant focus on formal learning and teaching? (Payne, 2010a). And so on. What value do I ascribe to the term 'value' and perceived 'usefulness' of any of these conceptual and ideological starting points? What other stating assumptions are available? If I am interested in, for example, the new wave of concern about ecoliteracy, might I be trapped by assumptions or 'baggage' I carry about psychological learning theory that is 'individual' as distinct from theory now available in the cognitive sciences and philosophy that promotes 'ecologically' embodied meaning-making and human understanding (Gallagher, 2005; Johnson, 2007)?

As noted, Sauvé's currents, and numerous other commentators, critics and researchers, are somewhat in agreement about the shift to a more relational and ecological view of the role, value and purpose of environmental education and its research. But what conceptual apparatus helps us see or glimpse a renewed 'ecocentric' vision and story for the future of environmental education research? And, perhaps, research in, about and for education for sustainable development?

Against the preponderance of 'low hanging fruit' of research discerned by Reid \& Scott (2006), their invitation to find 'harder to reach' varieties of theory might lead us into the fields of environmental ethics and ecopolitics, or even the need for an intelligent theory of experience in education that John Dewey (1938/1991) called for many years ago that, apparently, has not been developed (Fox, 2008) but has been addressed in the philosophy of nature (Toadvine, 2009). For example, researchers and teachers can learn a great deal 
from a long discussion in environmental ethics over the past three decades about ecocentrism. Its critical theorization does help us better understand the notions of 'ecopedagogy' and 'ecoliteracy' and can problematize their meanings in the framing of a research practice in context. Figure 1 summarizes the different ways of knowing about one of the most fundamental debates in environmental ethics that has only received modest attention in environmental education and its research.

Figure 1. Paradigmatic and conceptual orientations to the intersections of culture and nature: a 'social' and 'ecological' characterization (Payne, ongoing)

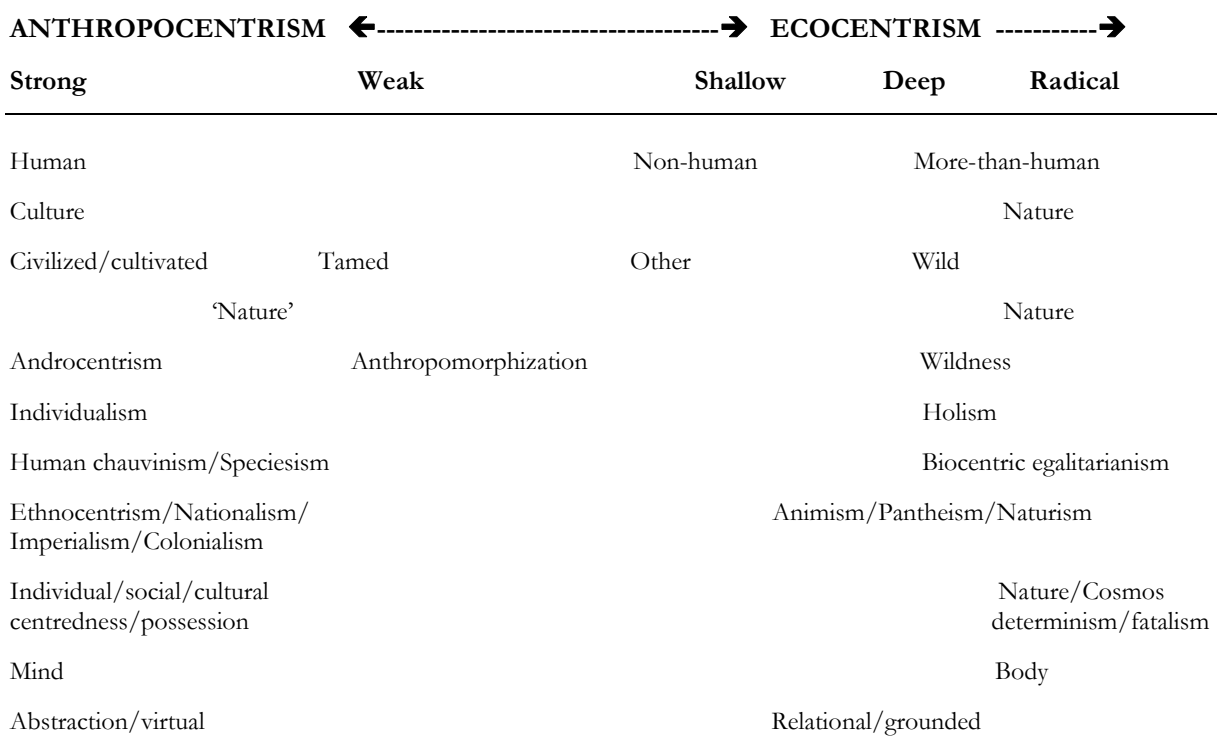

Calculative rationality/

Restoration

Earth wisdom

Instrumental reason

Values hierarchical thinking

Human over/against nature

Obligations/duties Intrinsic moral standing Rights

Nature over/against humans

Society over/against environments

Social spaces/Urbanscapes/Open spaces Places Land/seascapes

Culture over/against ecology

Ecology over/against culture

Industrial capitalism/socialism

Ecofascism/fundamentalism

Global/technological

Local

Quarry Supermarket Farm

Gymnasium Zoo Museum Silo

Indigenous/Endemic/Organic

Wilderness Cathedral/Shrine/Sanctuary

Environmental education and its research do have a major interest in developing and promoting a more ecocentric worldview and human understanding and, hence, 'big picture' frame for many of environmental, nature and ecological terms commonly used, be it experience, literacy, science, criticism, morality, ethics or bioregional and place understandings, and so on. 
The idea of 'conceptualization' of research is not new but in environmental education and its research does require we read and think outside purely educational discourses and practices, as illustrated above and reach for 'harder varieties' (Reid \& Scott, 2006). In the North/West, it is now fashionable to use expressions like 'different ways of knowing' and 'doing' but these calls for 'other' and 'difference' or plurality lack power or persuasion unless reconceptualization via, for example, notions like ecocentrism qualify and critique our current ways of knowing and doing. Armed with greater conceptual flexibility and insight, as well as the different languages that are used in different concepts, we are better able to reflexively consider the research problems and questions that often need sharper specification or a different way of knowing and posing them. In this way, we can enlarge the 'frames' and 'lens' we bring to our research and pedagogy.

Of course, there are many more theories relevant to environmental education and its research than what is on offer from environmental ethics, ecopolitics and, even, the philosophy of nature. The challenge here in (re) conceptualizing our work is to grasp those harder to reach varieties of theory that diversify and add meaning and value to our relatively common research and pedagogical efforts.

\section{(B) Contextualization}

Concepts 'live' in everyday, real world contexts. Ecocentrism needs to be more than a word, name, term, concept or theory. It cannot be a theory grabbed at conveniently by the researcher and forced to fit a potential research problem that, potentially, demands a different theoretical apparatus in making deep meaning and sense of various research questions. There are many environmentally or ecologically problematic circumstances and contexts that exist in time, over time and in different setting, spaces and places. Noted above, a great deal of environmental education research rightly focuses on formal schooling. There is the classroom context and its ethos and culture, including the relationship of teacher and students. There are, however, other contexts that powerfully shape the 'micro' context of the classroom and school, and notions of good pedagogy, or effective teaching, or best practices. But there has been very little conceptualization of the 'alternative' contextualizing forces on what happens in that 'micro' context.

To illustrate this important point, I briefly outline one example of research (Payne, 2005a, 2006c, 2009, 2010b) where I studied how the 'home' and 'household' provides a very powerful and enduring intergenerational environmental education (or not). Children bring to the classroom the 'learning' from the home. But environmental education research largely ignores that homebased culture of learning and socialization making it very difficult to 'fairly' research the effectiveness and value of classroom environmental education. Moreover, in conceptualizing research about the home context we might learn a 
great deal about that crucially important site and setting. We might even learn some lessons that can be transferred to the classroom and school contexts.

The main point here is that there are many messy layers of context, or layers in layers, that conceptually we need to understand critically in framing research.

\section{(C) Representation}

There are at least two senses in which we can think about representation, and its relationship with conceptualization, contextualization and legitimization. The first is traditional - who is represented in our research (see Reid \& Scott, 2006 Table 6, p. 582) and why? And who is doing the representing (Table 3, p. 581) from where (Table 9, p. 580)? Who and what is being excluded? And why, and from where? This first type of representation relates to the conventional question about sampling, but now needs to more assertively respond to concerns about social inclusion and justice in the aesthetics, ethics and politics of research if we are to seriously attend to the triad of ontology, epistemology and methodology (Robottom \& Hart, 1993). We need to struggle in our research with issues of what we mean by the researched and the researcher (Payne, 2005c)?

A second sense of representation is served by 'breaking' the word into two - 're' and 'presentation'. When we report our research to audiences at conferences, in workshops, in journal articles and books, or teach children in classes, what 'really' are we 'presenting' to those audiences? What can they believe, or are supposed to? How accurate are our words, numbers, texts, tables, figures, images, statistical treatments and so on? Do they mirror or correlate with the object of the knowledge we claim to have produced? Indeed, can our words, texts, numbers and so on ever be more than a partial re-presentation of the concepts and contexts we have studied? Moreover, even if we do accurately re-present our 're-search' we cannot be sure how the learner, participants, audiences will interpret or understand or 'know' about the research we have conducted and now disseminate. Questions about the issue of 'representation' are now prominent in the North/West discourse of environmental education research. These questions also relate closely to the way in which research is conceptualized and contextualized. A close relationship between conceptualization, contextualization and representation addresses concerns expressed about the internal coherence, commensurability and 'validity,' 'comprehensiveness' and, potentially, 'rigor' and plausibility of the research and its framing. It can support and extend, or qualify, more conventional representations of research that typically rely only on texts, words and numbers.

Over the past few years, some environmental education researchers have sometimes selectively used more aesthetic, artistic and poetic means of 'representing' the findings of their studies (for example, McKenzie et al., 2009). In my own research (for example, Payne, 2005b, 2006b, 2010c in press), I have used cartoons, sketches and drawings, reproductions of art works, poetry and 
photographs as well as tables and figures, often to support each other. The main aim of a more flexible representational strategy is to enact the otherwise rhetorical claim for 'different ways of knowing and doing.' (Payne, 2005b). Creative means of representation are gaining acceptance in the North/West as increasingly legitimate forms (Lyotard, 1984) of interpretation (Rosen, 1987), meaning-making, knowledge production (Rorty, 1979) and, inevitably, 'truth' claims in the period often referred to as postmodernity.

Postmodern approaches to research are not without commentary and criticism. Discussion and debate has occurred in this journal, in particular in volume 3, number 1, published in 2008. The issues of representation, interpretation, knowledge, value and 'truth' are likely to appear more frequently in debates about research (Denzin \& Lincoln, 2005), particularly in the changing configuration of environmental education research and its aesthetics, ethics and politics where those emerging genres of inquiry identified by Russell \& Hart (2003) gain more socio-ecological traction.

\section{(D) Legitimization}

Here we are most concerned with both the modern and postmodern question of what claims are we making 'post-intellectually' (Cooper, 2002) about 'truth?' Or, the 'good?' Or, the 'valuable?' Or, the 'right?' But, while 'contesting' the five techno-economic trends of neo-liberal globalized abstraction (James \& McQueen, 2002) and, perhaps now, from an ecocentric position? Too often in quantitative research, researchers 'hide behind' justifications of validity and reliability - but too often their frames have not been explained, nor have criticisms of the positivist paradigm been dealt with in terms of the conceptualization, contextualization and representation of the research. The same can be said about qualitative researchers. Sometimes they hide behind truth claims that are not plausible or credible. Often, the use of words fall short in meaning - they can't describe rich, deep experiences of, for example, some spiritual or horrific 'relation' with nature and its moral sensibility. And too often generalizations and transference of understandings are only ever imagined. Qualitative researchers often neglect the questions and concerns about framing within the conceptualization, contextualization and representation of their work.

Undoubtedly, any shift in the framing of research to an ecocentric vantage point will attract great attention from many researchers and educators wedded to the western tradition of knowledge that is so steeped in an anthropocentric posture and set of assumptions. But, in full view of the environmental problems we now encounter locally and globally in the everyday, environmental education researchers have the task of legitimizing ecocentric qualities and characteristics that flesh out the development of a socio-ecological theory for education. 


\section{An ongoing challenge for environmental education research}

If environmental education research is ecocentrically to become more aesthetic, ethical, political and 'useful' (conceptually and theoretically and empirically/practically) then there is now a demand for us to be more critically reflexive about building a robust body of knowledge, insight and evidence based on 'valuable' and 'valued' scholarly insight, development and practice. This demand calls for a review of the current configurations of environmental education and its research, as I have attempted to outline above. It also calls for researchers to 'take the lead' in imagining how certain trends can lead to the imagination of new politically aware configurations, as I have attempted all too briefly here.

To a large degree, the framing conceptualization, contextualization, representation and legitimization of environmental education research inevitably must address the ultimate question of what researchers 'do' - the production of knowledge (and assertions and critique of its 'truth' or otherwise, as both a current and historical process and an outcome, or dissemination to the public of that version of truth). If so, the notion of framing must be considered directly in relation to the question of what constitutes a theory of knowledge, its interpretation and the meanings it offers in terms of advancing the purposes of environmental education and which include the reversing of the ecologically problematic human condition. In framing we therefore need to examine the theory of knowledge we hold to and promote with its values while understanding the dynamic variations of knowledge and how we can then justify the frames we employ in our research, approach to knowledge production and its dissemination. I have called here for a view of environmental education and its research whose framing incorporates an aesthetics, ethics and politics into the ontological, epistemological and methodological assumptions and interests of inquiry, pedagogy, curriculum and policy.

The challenge is simultaneously formidable and simple but complex and demanding on our intellectual vibrancy - individually and collectively. Each of us simply needs to carefully consider the frame we work to. This can partially be achieved by examining the configuration, trends and issues for both environmental education and environmental education research identified above. For those who are practical and teachers there is a challenge to know, describe and critically reflect on Sauvés (2005) currents and what they offer how you might negotiate the curriculum or policy you are asked to work through.

For those who are more academic, or theoretical, and research others work, a similar challenge applies, noting the critical introduction of the political abstraction of globalized knowledge production and dissemination. Further consideration of the notion of framing can support this critical and reflexive undertaking. Finally, all of us working in environmental education, be it parent, teacher, principal, policy maker, academic or researcher are confronted with the same demand. What is valuable, useful and distinctive about environmental education and its research, and their configurations, that can foster an 
environmentally educated citizenry that is capable of knowing and undertaking creative, ethical and political action in imaginative, passionate and factual/evidenced relation to the very difficult socio-environmental conditions confronting every one of us?

\section{Acknowledgements}

Thanks are expressed to the numerous colleagues I now have in Brazil for the kind invitation to present at $V E P E A$ and conduct the three day workshop at UFSCar and for their generosity, support and warmth. There are too many to list here. Thanks also to Lucie Sauvé, Alan Reid and Paul Hart for their contributions to this article.

\section{References}

ARCHER, M. Making our way through the world: Human reflexivity and social mobility. Cambridge: Cambridge University Press, 2007

BECK, U., GIDDENS, A., \& LASH, S. Reflexive modernization: Politics, tradition and aesthetics in the modern social order. Cambridge: Polity Press, 1992.

COADY, T. (Ed.). Why universities matter: A conversation about values, means and directions. St Leonards, Sydney: Allen \& Unwin, 2000.

COOPER, S. Post-intellectuality? Universities and the knowledge industry. In S. Cooper, J. Hinkson \& G. Sharp (Eds.), Scholars and entrepreneurs: The universities in crisis. Carlton, Melbourne: Arena Publishing, 2002.

COOPER, S., HINKSON, J., \& SHARP, G. (Eds.) Scholars and entrepreneurs: The universities in crisis. Carlton, Melbourne: Arena Publishing, 2002.

DENZIN, N. \& LINCOLN, Y. (Eds.). The Sage handbook of qualitative research (3rd ed., p. 193-196; 198-199). Thousand Oaks: Sage Publications, 2005.

DEWEY, J. Experience and education. In J. A. Boydston (Ed.). The later works, 1925-1953: John Dewey. (Vol. 13, 1-62), Carbondale, Southern Illinois University Press, 1938/1991.

DIAMOND, J. Collapse: How societies choose to fail or survive. New York: Penguin, 2005

DILLON, J. \& WALS, A. On the danger of blurring methods, methodologies and ideologies in environmental education research. In A. Reid \& W. Scott (Eds.). Special Issue: Researching education and the environment: retrospect and prospect, Environmental Education Research, v. 12, n. 3-4, p. 549-558, 2006

FIEN, J. Education for the environment: Critical curriculum theorizing and environmental education. Geelong: Deakin University Press, 1993.

FOX, K. Rethinking experience: what do we mean by this word 'experience'? Journal of Experiential Education, v. 31, n. 1, p. 36-54, 2008.

FREIRE, A. Educacao para a sustentabildade: implicadcoes para o curriculo escolar e para a formacao de professors, Pesquisa em Educacao Ambiental, v. 2, n. 1., p. 141-154, 2007.

GALLAGHER, S. How the body shapes the mind. Oxford: Clarendon Press, 2005. 
GALLO, S. Pesquisa em educacao: o debate modernidade e pos-modernidade, Pesquisa em Educacao Ambiental, v. 3, n. 1., p. 33-58, 2008.

GAMBOA, S. Practicas de pesquisa em educacao no Brasil: lugares, dinamicas e conflitos, Pesquisa em Educacao Ambiental, v. 2, n. 1., p. 9-32, 2007.

GONZALEZ-GAUDINO, E. \& BUENFIL-BURGOS, R. The impossible identity of environmental education. In M. Mckenzie, P. Hart, H. Bai, \& B. Jickling (Eds.) Fields of green: Restorying culture, environment, and education. Cresskill: Hampton Press, p. 97-108, 2009.

GREENWOOD, D. \& SMITH, G. (Eds.). Place-based education in the global age: Local diversity. New Jersey: Lawrence Erlbaum, 2008.

HART, P. Reflections on reviewing educational research: (re)searching for value in environmental education. Environmental Education Research, v. 9, n.2, p. 241-256, 2003.

HART P. \& NOLAN, K. . A critical analysis of trends in environmental education research. Studies in Science Education, v. 34, p. 1-69, 1999.

JAMES, P. \& McQUEEN-THOMSON. Abstracting knowledge formation: A report on academia and publishing. In S. Cooper, J. Hinkson \& G. Sharp (Eds.), Scholars and entrepreneurs: The universities in crisis. Carlton, Melbourne: Arena Publishing, p. 183-206, 2002.

JICKLING, B. \& WALS, A. Globalization and environmental education: looking beyond sustainable development. Journal of Curriculum Studies, v. 40, n. 1, p. 1-21, 2008.

JOHNSON, M. The meaning of the body: Aesthetics of buman understanding. Chicago: University of Chicago Press, 2007.

KENWAY, J. \& FAHEY, J. (Eds.). Globalizing the research imagination. London: Routledge, 2008.

LAW, J. After method: Mess in social science research. London: Routledge, 2004.

LOUV, R. Last child in the woods: saving our children from nature deficit disorder. Chapel Hill: Alonquin Books, 2005.

LYOTARD, J-F. The postmodern condition: A report on knowledge. Minneapolis: University of Minnesota Press, 1984.

MARIN, A. Pesquisa em educacao ambiental e percepcao ambiental, Pesquisa em Educacao Ambiental, v. 3, n. 1., p. 203-222, 2008.

MCKENZIE, M. Scholarship as intervention: critique, collaboration and the research imagination. Environmental Education Research, v. 15, n. 2, p. 217-226, 2009.

MCKENZIE, M., HART, P., BAI, H., \& JICKLING B. (Eds.) Fields of green: restorying culture, environment and education. Cresskill, NJ: Hampton Press, 2009.

NIELSEN, R. The little green handbook: A guide to critical global trends. Melbourne: Scribe, 2005.

ORR, D. Ecological literacy: Education and the transition to a postmodern society. Albany: SUNY Press, 1992.

PALMER, J. Environmental education in the 21st century: Theory, practice, progress and promise. New York: Routledge, 1998.

PAYNE, P. Embodiment and environmental education, Environmental Education Research, v. 3, n. 2, p. 133-153, 1997.

PAYNE, P. Postmodern challenges and modern horizons: education 'for being for the environment. Environmental Education Research, v. 5, n. 1, p. 5-34, 1999. 
PAYNE, P. Families, homes and environmental Education. Australian Journal of Environmental Education, v. 21, p. 81-95, 2005a.

PAYNE, P. 'Ways of doing' learning, teaching and researching. Canadian Journal of Environmental Education, v. 10, p. 108-124, 2005b.

PAYNE, P. Lifeworld and textualism: reassembling the researcher/ed and 'others.' Environmental Education Research, v. 11, n. 4, p. 413-431, 2005c.

PAYNE, P. Environmental education and curriculum theory. Journal of Environmental Education. 37(2), p. 25-35, 2006a .

PAYNE, P. The technics of environmental education. In A. Reid \& W. Scott (Eds.). Special Issue: Researching education and the environment: retrospect and prospect, Environmental Education Research, v. 12, n. 3-4, p. 487-502, 2006b.

PAYNE, P. Postmodern oikos. In McKenzie, M., Hart, P., Bai, H., \& Jickling, B. (2009). Fields of Green: Restorying culture, environment, and education. Creskill, NJ: Hampton Press. p. 309-321, 2009.

PAYNE, P. The globally great moral challenge: ecocentric democracy, values, morals and meaning, Environmental Education Research, v. 16, n. 1, , 153-171, 2010a.

PAYNE, P. Moral spaces, intergenerational influences and the social ecology of families in environmental ethics education, Environmental Education Research, v.16, n. 2, 2010 b.

PAYNE, P. Remarkable-tracking, experiential education of the ecological imagination, Environmental Education Research, 2010c in press..

RAVEN, G. Methodological reflexivity: towards evolving methodological frameworks through critical and reflexive deliberations, In A. Reid \& W. Scott (Eds.). Special Issue: Researching education and the environment: retrospect and prospect, Environmental Education Research, v. 12, n. 3-4, p. 559-570, 2006.

REID, A. Environmental education research: will the ends outstrip the means? Environmental Education Research, v. 15, n. 2, p. 129-154, 2009.

REID, A. \& SCOTT, W. (2006). Researching education and the environment: retrospect and prospect. In A. Reid \& W.Scott (Eds.). (2008). Researching education and the environment: Retrospect and prospect. London: Routledge, 325-342.

REIGOTA, M. O estado de arte de pesquisa em educacao ambiental no Brasil, Pesquisa em Educacao Ambiental, v. 2, n. 1., p. 33-66, 2007.

2007

RICKINSON, M. Learners and learning in environmental education: acritical review of the evidence. Environmental Education Research, v. 7, n. 3, p. 208-320, 2001

ROBOTTOM, I. Participatory research in environmental education: some issues of epistemology and methodology, Pesquisa em Educacao Ambiental, v. 1, n. 1., p. 11-26, 2006.

ROBOTTOM, I. \& HART, P. Research in environmental education: Engaging the debate. Geelong: Deakin University Press, 1993.

RORTY, R. Philosophy and the mirror of nature. Princeton, NJ: Princeton University Press, 1979.

ROSEN, S. Hermeneutics as politics. New York: Oxford University Press, 1987.

RUSSELL, C. \& HART, P. Exploring new genres of inquiry in environmental education research. Canadian Journal of Environmental Education, v. 8, p. 5-8, 2003.

SANTOS, M. As diferentes correntes epistemologicas e suas implicacoes para a pesquisa em educacao ambiental, Pesquisa em Educacao Ambiental, v. 2, n. 1., p. 67-94, 2007. 
2007.

SAUVÉ, L. Being here together. In M. McKenzie, P. Hart, H. Bai, \& B. Jickling (Eds.) Fields of green: Restorying culture, environment, and education. Cresskill: Hampton Press, p. 325-336, 2009.

SAUVÉ, L. Uma cartografia das correntes em educação ambiental. In Sato, M. et Carvalho, I. (Dir.). Educação ambiental - Pesquisa e desafios. Porto Alegre : Artmed, 17-46, 2005.

SCOTT, W. 2009. Environmental education research: 30 years on from Tbilisi. Environmental Education Research, v. 15, n. 2, p. 155-164, 2009.

TOADVINE, T. Merleau-Ponty's philosophy of nature. Evanston, Ill.: Northwestern University Press, 2009.

Artigo: recebido em 23/11/2009 - aprovado em 21/12/2009 